\title{
The Fifth Epoch: Socio-Economic Approach to Sustainable Capitalism
}

David M. Boje

New Mexico State University

Yue Cai Hillon

Western Carolina University

Follow this and additional works at: https://digitalcommons.uri.edu/mgdr

Part of the Business Administration, Management, and Operations Commons, Other Economics Commons, and the Strategic Management Policy Commons

\section{Recommended Citation}

Boje, David M. and Hillon, Yue Cai (2017) "The Fifth Epoch: Socio-Economic Approach to Sustainable Capitalism," Markets, Globalization \& Development Review. Vol. 2: No. 1, Article 2.

DOI: 10.23860/MGDR-2017-02-01-02

Available at: https://digitalcommons.uri.edu/mgdr/vol2/iss1/2

This Article is brought to you for free and open access by DigitalCommons@URI. It has been accepted for inclusion in Markets, Globalization \& Development Review by an authorized editor of DigitalCommons@URI. For more information, please contact digitalcommons-group@uri.edu. 
The Fifth Epoch: Socio-Economic Approach to Sustainable Capitalism

\section{Markets, Globalization \& Development Review}
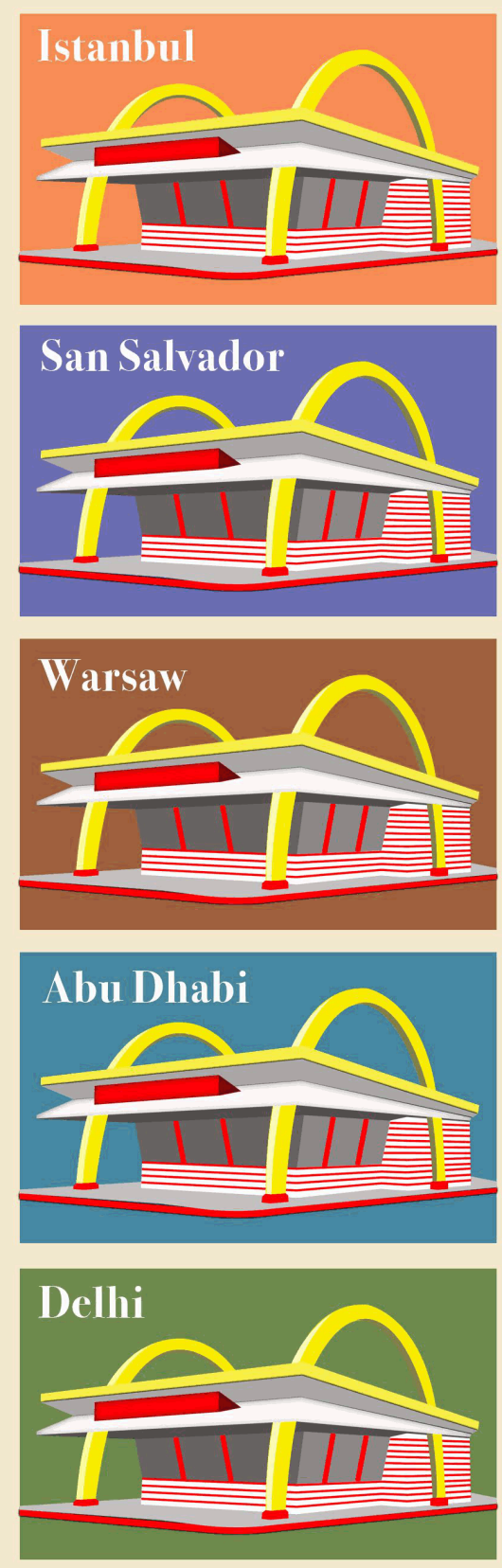
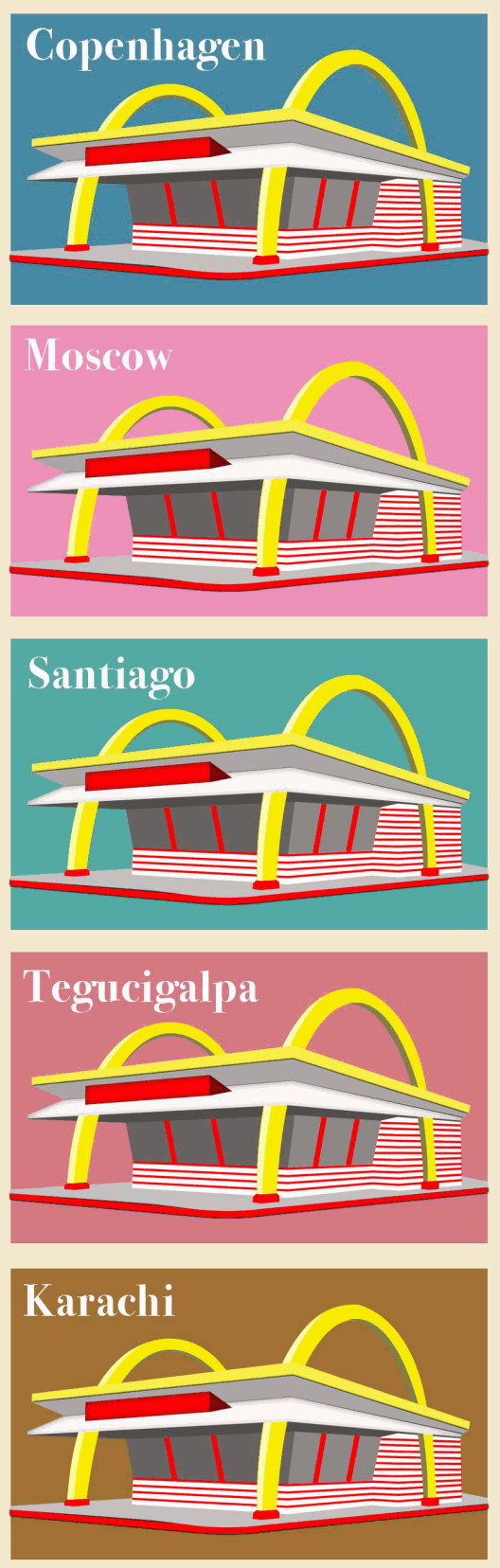
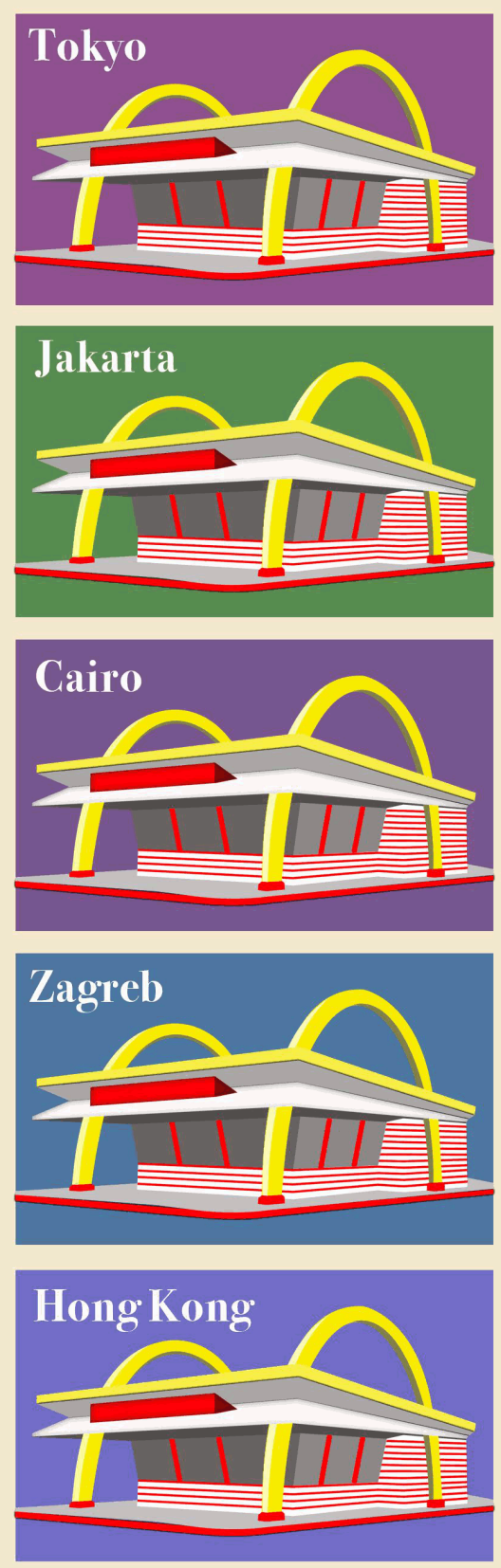

This article is available in Markets, Globalization \& Development Review: https://digitalcommons.uri.edu/mgdr/vol2/ 


\section{The Fifth Epoch: Socioeconomic Approach to Sustainable Capitalism}

\section{Introduction}

What role does global capitalism play in economic instability, wealth inequality, and consumption-fueled socio-ecological destruction? Global capitalism has escaped control of the nation-states that are facing a downward-spiraling crisis of legitimacy. Nations are failing to address the social grievances of local working conditions and their middle classes seem to be in downward mobility. There is unemployment, hunger, and insecurity for billions of people. Meanwhile, global elites are neither countering the erosion of the system's authority nor creating an ethical global economy. Is this, then, a great collapse of world civilization akin to the Dark Ages? Is a socially responsible capitalism possible?

In the Adam Smith era before his calls for a freer market gained traction, mercantile capitalism affected lives, but did not have much impact on the global environment's resources. Since that time, global capitalism has had several incarnations as it has morphed and grown into a force capable of threatening human habitat from patterns of over-production and over-consumption. It has reordered society to reproduce these patterns, changing the climate, borrowing natural resources from future generations, and reducing biological diversity. We are locked into a form of global capitalism that is killing the planet's ability to sustain humanity. The situation is catastrophic, but to regain our footing, we must trace backward from the destructive consequences to change the economic sociomaterial roots of our problems.

Our path takes us on an exploration of the failure of socially responsible capitalism's empty rhetoric before arriving at a possible real solution, in the form of Savall et al.'s (2015) socioeconomic sustainable capitalism (SESC). We describe this alternative economic universe as a form of apolitical and decentralized democracy essential to the healthy functioning of civil society. Although SESC is primarily meant to diffuse into society through the relations of people and work, it is not simply a matter of economic necessity. Rather, SESC is rooted in the daily lives of everyone because it places human potential as the source of sustainable value creation and recognizes that management is a constant individual and proximate negotiation to maintain the cohesive relations essential for productive and engaged citizens to prosper. The extended and long-term community impact of SESC supports a socioeconomic system to mediate 
an ongoing dialogue to assure the continuance of an equitable social contract in a tradition of responsible humanism.

This article begins with an overview of increasing wealth disparity and the evolution of capitalism through four epochs that brought us to this stage. We then descend the pyramid for a closer look at scholarly factions that are often at odds with one another: those promoting exploitation of the world's most vulnerable citizens, those arguing for social and economic justice, and some merely studying issues with a curious detachment. From the corrosive influence of speculative financial capitalism (Dholakia 2011) all the way to the bottom of the pyramid, we next explore the myth of corporate social responsibility and then propose SESC as a means to begin a new era of genuinely responsible capitalism.

Henri Savall has recently been named to the French Legion of Honor for his life's work that has shown that a genuine form of socially responsible capitalism can exist. SESC has evolved from over 40 years of intervention research under his direction to reinvent an active and answerable form of enterprise management. Exploring beyond the mechanics of Savall and Zardet's (2008) intervention research as an approach for implementing socioeconomic management, we delve into the global implications of a speculative financial capitalism that thrives on crisis and destruction. This ideology is not one of the fundamental relations governing human-centered value added processes and substantive messages derivable from Savall et al. (2015) offer hope for a life sustaining form of capitalism. From their proposal, we have worked out a new dialectic and narrative grammar of socioeconomic organization that we hope will engage critical management scholars in a new dialogue.

\section{A Wealth of Disparities}

The world is saying no to globalization just as it did 100 years ago. Then and now, populist causes of progressives, nationalists, and isolationists share the stage in competition to co-create the script. Globalization, however, is not the cause but just the means by which reckless $21 \mathrm{st}$ century global capitalists are consuming the future of $90 \%$ of the world's population. The discourse of $99 \%-v s-1 \%$ presupposes a sense of unity among the global masses that simply does not exist. Wealth inequality is stratified into aspiring and upwardly mobile groups that want desperately to escape the huddled masses yearning for more favorable treatment from free market economics.

Estimates vary, but Wood's (2013) multi-data source compilation shows that roughly $1 \%$ of the world's population owns $46 \%$ of all global wealth and resources, the next $9 \%$ owns $40 \%$ of total wealth, the next 
$40 \%$ of the population owns $13 \%$, while the remaining $50 \%$ of the population owns only $1 \%$ of the planet's material and financial resources. Within that bottom $50 \%$, the $1 \%$ of global wealth falls disproportionately to the top sliver as well. While one might expect to find such a disparity within developing nations, the bottom $80 \%$ in the United States owns only $11 \%$ of the country's wealth, even less than the global average. Most alarming of all, it is estimated that only $10 \%$ of the population own all of the world's potential income producing assets.

If there is hope for a genuine socially responsible alternative to 21 st century global capitalism, then we must search for a new means of value creation to offer more than the traditional economic production function that pits capital against labor. Economic liberalism was held in check during the 30-year post-World War II Keynesian cycle that essentially created the American middle class, thereby bringing a balance of power to the production function (Cowie 2016; Herman 2012). As current global wealth disparity statistics show, that idyllic balance is gone and we are at a loss to find a counterbalance to the neoliberal force that has moved the market ahead of social good (see, e.g., Özgün, Dholakia and Atik 2017).

\section{Crisis of the Fourth Epoch of Global Capitalism}

Before we continue in our search for a solution to perpetual economic crisis, we will briefly look at how we got to now. Historians might disagree on how many distinctly different eras of capitalism have come and gone and overlapped, but we will present an evolution through four main epochs. The first three are clearly over and the fourth would likely be unrecognizable as a form of capitalism to the mercantilists in the first epoch of pre-industrial Adam Smith resource-based and Ricardian economics (see, for example, in this issue of the journal, Bouchet 2017 and (cc). This first epoch spans the 16th to 18th centuries, with roots stretching back to the slow transition from feudalism to mercantilism, which began around 1350. Entrepreneurs of this epoch were realists who bore the risk for a venture, assuming unlimited liability for all debts incurred. Success could bring wealth and failure could bring a lifetime of personal bankruptcy passed on for generations of debt repayment. Accounting also had a prudent realist quality, as static views on depreciation required all costs to be recovered prior to profit taking in order to conserve capital (Richard 2015).

The second epoch of industrial capitalism spanned the first and second industrial revolutions, extending throughout the 19th and into the early 20th century. The stirrings of change in finance and industry trace back to approximately 1760 , and the transition to the next era was well 
underway by 1929. More than any other, this epoch contains the origins of our modern crises, as speculators gained a strong foothold in reducing risk with limited liability, relaxing accounting practices from prudent static to dynamic depreciation, and taking unrealized future profits (Richard 2015). Limited liability for investors was somewhat offset by unlimited liability of laborers - whose lives were shortened by unsafe and inhumane working conditions. To the present day, human potential remains a casualty of this unlimited labor liability.

It is fair also to note that in this second epoch, the market economy separated from society and gained power over human life (Herman 2012). This sense of "market" does not refer to the ordinary fluctuation of prices for exchanging goods through commerce, but rather, it means that society is governed by speculative investment economics or stock market thinking. Spanish economist Germán Bernácer's reforms of Spain's economic system focused on regulating speculative financial systems, particularly in banking, and stimulating productive economics. Bernácer confronted speculative capitalism in order to develop the "real" economy (Savall et al. 2015). It is not at all coincidental that his work began at the end of the second epoch of global capitalism, an epoch from which we can trace the reversal - from entrepreneurs as all-risk bearing managers of long-term ventures, to risk-externalizing speculative financial capitalists. Savall et al. (2015) assume that the reason for the 2008 world financial crisis was runaway unregulated speculative markets - often in the form of casino-like financially engineered bets - that drained productive resources needed to invest in building entrepreneurial and intrapreneurial activity in companies.

The third epoch of corporate capitalism - subsidized by nation-state debt - began near the end of the second industrial revolution and saw the rise of the military industrial complex. This epoch spanned roughly from 1929 to 1980, beginning with a regulated market and transitioning to laissez-faire. As noted earlier, economic liberalism was held in check by Keynesianism, but this social countermovement was ultimately defeated by the neoliberal takeover of the state (Herman 2012). From an accounting perspective, dynamic depreciation transitioned to futuristic rules to discount company returns ever faster into present profits (Richard 2015). The primacy of long-term capital conservation yielded to the demands of short-term investors who bore no risk for company failure and who forced changes to accounting practices to make profits appear faster on the books (i.e., not the actual creation of value). In contrast to the first epoch's necessary commitment to manage for long-term firm success, the emphasis by the end of the third epoch had shifted compellingly to the 
immediate present, and accounting rules prioritized profitability to shareholders rather than to sustaining the organization.

Through the first three epochs, the meaning of capital and the means of value extraction clearly changed. Capital has always been somehow separate from a venture, yet it provided the economic power to create value through a production function involving labor and material resources. Pre-industrial ventures were self-capitalized by owner/entrepreneurs or capitalized through debt at very high interest rates. Value creation and extracted profit were tied directly to a physical reality, such as in production processes that added value by transforming basic resources. Capital was integral to a venture, brought in and protected. Well into the second epoch, capitalists extracted profit from the surplus value produced by laborers. In the third epoch, they added accounting tools to reclassify company reserves that had been held against future uncertainties, thereby converting assets to present extractable profit. By the end of the third epoch, the value creation that had safeguarded capital in earlier epochs had been replaced by debt, directly borrowed against anticipated future returns and reclassified as profit for speculative investors. Therefore, by the end of the third epoch, capitalists had learned to extract surplus value in multiple ways: from resource conversion, from laborers, from company reserves, and ultimately from the future. In this evolution, capital gradually migrated out of the value creation process. Bernácer saw these macroeconomic developments before the Great Depression and realized that speculative markets were producing revenues without work, without entrepreneurial risk, without creating real value added, and without the possibility of sharing gains among all economic and social actors (Savall et al. 2015).

The third epoch gave power to the speculative market economics discourse that is used to wage war on social and ecological concerns in the fourth epoch. The social has fallen prey to the economic. Capitalism of the fourth epoch no longer creates value, but it has the power to destroy the means by which others do. The fourth epoch dates from approximately 1980 to the present, with roots definitively stretching back to the 1971 appearance of corporate social responsibility. In the fourth epoch, financial capitalists turned to the reserves of global society and extracted the stored value in savings, pension funds, and houses. They worked through derivatives, often several steps removed from a physical or monetary asset (see, e.g., Dholakia 2011). For instance, debt was offered to consumers to buy beyond their means. Then the bad debts-in-the-making were bundled into securities and sold to large investors around the world, many of whom were responsible for safeguarding savings and pensions. 
When it all collapsed, governments bailed out the fourth epoch capitalists that had both caused and gotten rich off of the entire scheme.

For the $10 \%$ who own all of the world's productive resources, a transnational regulatory superstructure protects them from the endemic existential crises of cyclical economic collapse. This is the age of mass extinctions and ecological degradation. Investment in this epoch is "based upon the expectation of future returns [and] flows to forms of fictitious capital which are purely speculative and not part of the value creation process" (Cooper 2015, p. 64). Just as natural resources were mined and transformed in the early epochs, and more recently via 'fracking' forms of intense extraction, fourth epoch 'financial frackers' pump debt into society to extract stored financial resources. The metaphor has a reality to it in that a toxic sludge is left behind to diminish planetary hopes for the future (e.g., the term 'toxic assets' was widely in vogue after 2008). We tend to look to the 2008 financial crisis as the material epitome of this epoch, but attention to the bottom of the pyramid is perhaps a better illustration of the corrosive attack on communities and human potential by fourth epoch global capitalists.

\section{Descending the Pyramid}

Prahalad and Hart (2002) claimed that poverty could be alleviated by multinational corporations (MNCs) tailoring their sales and marketing to the four billion potential consumers living on less than $\$ 1,500$ per year at the bottom of the pyramid (the BOP). As we have already noted in our discussion of global wealth disparities, wealth is concentrated such that the majority of these four billion "consumers" actually live on about a third of this annual amount. A crucial element of the BOP-targeted proposals is to increase the buying power of the poor by providing easy access to credit, namely by replacing the community-based practices of lenders such as Grameen Bank with more profitable technology-driven lending management solutions. While Prahalad and Hart (2002) mentioned a second crucial element to poverty alleviation, they failed to make a viable case as to how the poorest in the world would earn enough beyond subsistence needs to afford the MNC products targeted at them. The implication of the second element was that access to the global market would allow these new consumers to raise themselves out of poverty, and further, that MNCs would somehow be a new force for good in adopting an environmentally and community friendly approach along with the familiar low-margin high-volume production practices. The hidden means to increase consumption, however, was through debt (for a recent study of 
the dangerous seduction of debt and MNC products to BOP segments, see Yurdakul, Atik and Dholakia 2017).

Studies of programs to help the persistently poor at the bottom of the pyramid offer convincing evidence to the contrary, that access to consumer debt and attention from MNCs does not alleviate poverty. Banerjee et al. (2016) found long-term improvements to income, food security, and health from programs that give productive assets to carefully selected families, along with weekly support from counselors for up to eighteen months. This sort of focused assistance offers both an incomegenerating asset and the training necessary to realize and sustain the benefits long after the program ends.

The critical role of human potential in socioeconomic sustainable capitalism (SESC) also surfaces in studies couched in traditional economic terms. For instance, Beaman et al. (2014) provide evidence that micro-loans tend to offer productive benefits to borrowers who already know how to extract higher marginal returns from an influx of capital. The advanced skills needed by a successful borrower might seem obvious when taking into account the loan terms of their study (e.g., $25 \%$ interest, $3 \%$ fees, $10 \%$ mandatory savings). While empirically testing this loan selfselection bias, they found that in contrast to loan recipients, randomly selected grant recipients could not generate higher marginal profits from their current activities. Sustainable improvement to value creation requires more than an asset or access to capital.

Similarly, Loiseau and Walsh's (2015) survey of microfinance in seven countries found that access to credit did not increase consumption, income, or profit. Again, programs lacked training and support to help borrowers access their unique value adding potential, while lenders were reaping on average $37 \%$ interest with very low default rates. Therefore, evidence from reality does not support Prahalad and Hart's (2002) theory of debt-based consumption of MNC products as a viable route up from the bottom. There is evidence, however, to suggest that the fourth epoch of capitalism has begun to colonize microfinance with predatory lending practices. For instance, one publically traded micro-lender charged 145\% annual interest with a default rate of only $1 \%$ (Banerjee et al. 2015). In effect, the increased consumption of financial products may be broadening the base of the pyramid instead of alleviating poverty.

Why is this a dangerous development? The myth supporting free market beliefs is that by extending credit to those least able to consume, the economy is stimulated by immediate spending, but even more so by an abstraction of capital that anticipates future market growth from continued expansion of credit (Chabrak and Gendron 2015). From this 
perspective, low interest rates and long-term training and support for borrowers are unnecessary costs that serve to reduce the murky abstraction of capital.

It is much easier for the BOP-microfinance antenarrative (Boje $2001 ; 2011)$ to conjure a façade of social responsibility when individual human faces have been excluded from the social dimension (to 'hear' some BOP human voices, see Yurdakul, Atik and Dholakia 2017). That the poor have attracted the attention of large banks and investment firms should not go unnoticed either. The rise of financial capitalism in the fourth epoch has firmly established the neoliberal practice of government bailouts for speculative investors, thereby allowing them to thrive on the economic crises and chaos that they create (Chabrak and Gendron 2015). This confirmed expectation shifts the risk and consequences to governments, a collective abstraction of the people exploited in the first part of the spiral.

Stiglitz (2012) observes that for the most part, the $1 \%$ did not become fabulously wealthy on their own or by contributing great knowledge or innovations to transform our society and economy. He adds that there are only two basic ways to gain wealth: create it in a process that adds to the overall abundance or, appropriate it from others and destroy some of it in the process. Further, Stiglitz (2012) notes that a majority of global citizens would be willing to overlook the social injustice, exploitation, and environmental degradation if only the market had kept its promise to improve their well-being. With the prevalence of destruction over creation through four epochs, capitalism has become neither social nor responsible. Instead, capitalism's role has become to protect the resilient institutional structures promoting the systemic growth of wealth and resource inequality on a global scale.

\section{Socially Responsible Capitalism?}

The first four epochs of global capitalism have evolved successively from prudent small-scale entrepreneurship and have ultimately transformed capitalism into a global threat-nexus of reckless wealth appropriation. There is no way for this system to continue its historical evolution and ever become a genuine socially responsible form of capitalism. At this stage, it cannot even collapse into itself and devolve to an earlier form of capitalism. Speculative financial capitalism is a singularity. We are not proposing an end to capitalism, but - as a viable alternative form of capitalism - SESC is a return by a different path to venture management for long-term sustainable value creation. As such, it bears no resemblance 
whatsoever to the fourth epoch incarnation of non-social, irresponsible, ultra short-term, and speculative global capitalism.

We have traced how capital became disconnected from value creation, but there is another disconnect that is an essential focus of SESC. The most troubling limitation of traditional economics is its disconnection of human capital from value creation. A person born into a rich family, by definition, has more human capital than someone from a poor family. As Zhang (2015) observes, the market rewards mediocrity among the rich at a disproportionately higher rate than exemplary work by the poor. Human capital has also been viewed narrowly by historians, defined in terms of a knowledge of science and invention possessed by only a few great men and women of the industrial revolution, but this view ignores the multi-skilled toolmakers who brought to life designs from drawings and incomplete instructions (Ó Gráda 2014). Basic education and apprenticeships produced a small army of workers with essential knowledge and skills to tinker with and improve designs for economically viable production in all fields (Meisenzahl and Mokyr 2012). Human capital is therefore a narrowly defined term used by some fourth epoch management scholars to protect the right of the $10 \%$ to restrict the real economy of value creation from functioning.

Savall (1981) found years ago that the traditional emphasis of economics and accounting on labor and capital fails to acknowledge that people create value from their own human potential. Savall created an approach for organization change and development, applied it with scientific rigor, and refined both its theory and practice extensively over a 40-year period (Savall 1981; Savall and Zardet 2008, 2011). SESC was created with the recurring crises of global capitalism in mind, but most of the experimentation and development for its approach to socially responsible and sustainable enterprise management was done with the sort of family entrepreneurial businesses and going concerns that were viable in the first and second epochs of capitalism. This development process was still possible in France, well after the rest of the world had succumbed to the fourth epoch. France was relatively late to be colonized and converted by management missionaries of the American business school doctrine. Primarily, this means that quite a different understanding of management held out as a scientific study, both technical and social, for roughly half a century longer in France than in America (Savall and Zardet 2014). Also, France has resisted the shift to futuristic fair value accounting that allows large investors to dictate that a company must be managed for high short-term returns on investment (Richard 2015). Futuristic capitalist 
financial accounting ironically has no regard for the future of society and works against sustainable management practices.

Although non-critical scholars might dismiss SESC as only workable in a limited French context, Savall's work profoundly demonstrates that the socioeconomic context of capitalism was reshaped to favor the destructive fictitious capital of the fourth epoch over the human engine of value creation. Onorati (2007) expressed frustration at the fact that "economy" has had different meanings throughout human history, with the most notable differences between primitive and market societies. Although they had fully functioning social systems, from a modern market economist's perspective, these primitive societies are considered uncivilized. The deeper implication is that reciprocity and redistribution are antiquated concepts in a capitalist speculative market society. The French political-economic model, however, incorporates some of these humanistic pre-modern elements. It has strong state roles of provider, planner, and regulator - roles that critics claim inflexibly limit growth in good times, while arguably cushioning the country against major shocks like the 2008 crisis (Economist 2009). Therefore, we can add to Onorati's (2007) complaint that the concept of "economy" also differs substantially from country to country. This "problem" is fortuitous because it offers compelling evidence that the shadow of speculative market economics has not darkened the entire world and offers hope for restoring some sustainable economic threads within the socio-ecological fabric of humanity.

Economic ideology is based on scarcity and all eras of capitalism have promoted the doctrine that the wealthy are the natural and rightful guardians of the earth's resources (Fuller 1983). Carnegie's (1889) thoughts on charitable redistribution of his income, arguably derived from socially irresponsible means, is part of the counter memory of late 20th century socially responsible capitalism. To retain the social order of the Gilded Age, American management - founded on technocratic efficiency and rational modernity - falsely promised that through its guidance, scarcity would yield to abundance in all facets of human civilization (Maier 1970).

Smith (2015) emphasized the "generally accepted" aspect of Generally Accepted Accounting Principles (GAAP) in describing the conundrum of accounting standards setting, that the authority of a board to issue guidance is derived from the participation and opinions of practicing accountants who view restrictive standards as illegitimate. Consequently, the fourth epoch claims authority to lightly regulate itself in financial accounting, an active practice that has quickened the pace of 
parasitical wealth extraction. While Keynes offered a reductionist response to Germán Bernácer's noted deficits of economic liberalism, his macro economic "solution" did not challenge the power of fictional capital and speculative markets to rule over real socio-ecological concerns. The drive for productivity and profit in the present created a tension with the future, when workers assumed that they would be rewarded for their sacrifices. Perhaps the greatest deficit of neoclassicism and liberalism is that the promise of the future never arrives. A few in the present consume the future. Bernácer proposed an economic system without these unenforceable promises, between the materialist extremes of second epoch capitalism and Marxism (Savall 1981).

François Perroux directly critiqued Keynes' silence on the asymmetrical power relations that render human agents passive against the seemingly irreversible imbalance of inequality. Perroux noted that Keynes' worldview denied the interdependence and active capacity of human agents to transform themselves and their environments. This assumed lack of social participation in economic life raised a broader critique that economic ideologies - neoclassicism and liberalism alike were based on non-scientific doctrine, mere beliefs on how fictional human agents behave exclusively within a market society (Savall and Zardet 2011). The authority vested in fictional agents to self-regulate their work with fictional capital seems to be absolute.

The myth of a socially responsible corporation was first narrated into academic discipline in the 1970s in the form of a call to privatize government services when social good could be profitable (CED 1971). This same reasoning was reflected in the UN Global Compact, a bluewashing tool - the term 'bluewashing' referring to corporate-UN collaboration to project a spurious sense of responsibility - created for multinationals in the era of 21 st century speculative financial capitalism (Bruno and Karliner 2002), a grotesque parody in a new Gilded Age. Corporate social responsibility has always been devoid of an ethical component, sustained instead by greenwashing counter-memory to promote an image of business for social good (Boje and Massoud 2014). Beneath the appearance, we find supremacy of profit, the right of wealth to guard the earth's resources, and an unshakable belief in market solutions for every problem.

In conflict with being and ethical action is the appearance of market economy symbiotically entwined with society, the appearance of corporate stewardship, and the appearance of responsible conduct. A critical reading of socially responsible capitalism reveals that in place of ontology, one finds only situated appearance. Badiou (2004) distinguishes being 
from appearance in that ontologically, "the possible and the real become indiscernible"....[as] "no existence is allowed which does not presuppose another," whereas appearance is unnaturally tied only to situation, to qualities without existence, and "there is something violent about appearance" (pp. 180-181).

Philosophically, global financial capitalism as only appearance is a false economy, separate from being, lacking substance, yet has the force of a parasitical singularity that has drawn humanity onto a divergent path. It has hidden a dialectical perspective in which it cannot participate or mediate. When we accept that the non-being and non-place aspects of appearance relegate it to nothingness in the strong sense of an ontological zero, its sudden absence reveals an economy of both the ontological and the nihil of immanent potential, including "the possibility for a non-economical, non-ontological thought" (Hryschko 2010, p. 211). That is to say, a true Hegelian dialectic (Zizek 2012) of the real and the potential economy comes into focus after lifting the veil of appearance.

Our exploration from the top to the bottom of the pyramid shows that roughly $90 \%$ of humanity transacts with a daily economy to meet basic needs while a shadowy destructive force seeks to appropriate any modest wealth that accumulates. It is unworkable and ultimately destructive for our socioeconomic system to stand on ephemeral appearance. Critical perspectives may also have fallen into the nothingness traps of speculative versus non-speculative, free versus regulated markets, or financial versus other varieties of capitalism.

An economic system of the real and potential must be inscribed in the daily lives of everyone because that places human actors at the heart of economic value creation and allows individual and collective responsibility for sustainability (Savall et al. 2015). The strength of the SESC proposal is in its conceptual innovation. In combining the insights of Bernácer and Perroux, Savall et al. (2015) reveal that the debate between economic liberals and neo-classicists assumes a fatalist inevitability, as it is fundamentally about how to live with a destructive beast. A socioeconomic perspective reintroduces an ontic economics as part of a new dialectic to question the inevitability of speculative markets. A productive dialogue can ensue from the collective insights of Badiou, Hryschko, Bernácer, and Perroux that recognizes speculative financial capitalism as a singularity beyond and separate from the real and potential economy. 


\section{Fifth Epoch: Socioeconomic Sustainable Capitalism}

In an Einstein universe, nature is unified by a causal fabric and "spacetime is structured by the events taking place," although the same event is not at all consistent across different observers (Nicolaidis, 2010, p. 96). The meanings of events and even their temporal order varies with an observer's perspective. In our economic universe, the increasing inequality from wealth concentration exerts a force similar to gravity in that it appears to warp the fabric of our sociomaterial reality, perhaps ever more so as we descend the pyramid.

In contrast, Zizek (2012) tells us that in Hegelian relativity, it is the curved geometry of spacetime that gives rise to concentrations and configurations of matter already present and dispersed in a not so empty void. An economic universe can be reshaped: we can think of the Bernácer-Perroux geometry giving rise to SESC and a different structure of economic organization spacetime to manage value added processes. The antenarrative of global capitalism was reshaped in each epoch by the dynamically evolving social and economic contextual fields. Savall et al (2015) propose that we reshape the fabric once again, but this time, for the benefit of all. Nicolaidis (2010) proposes that a pragmatic relational ontology "brings closer together the created and uncreated" (p. 95). This is the element of human potential that the fifth epoch seeks to liberate. In spite of the destructive beast's best efforts, somehow $90 \%$ of humanity is surviving, albeit just barely hanging on, by drawing on hidden human potential.

Collective insights from Badiou (2004), Hryschko (2010), and Zizek (2012) offer a structuralist grammar for narrativity of SESC when mapped onto a Greimas discursive semiotic square (Greimas and Porter 1977). The generic Greimas square upon which the syntax of alternative economic universes can be modeled locates the ontological and nonontological contraries at the upper vertices and the economic and noneconomic subcontraries at the lower vertices. Diagonals trace the disjunctions or contradictory relationships. "This arrangement offers an upper surface grammar as an exchange axis for object-values and a lower level at which agents may situate these same values in and out of narrative action" (Hillon 2017). Thus, being and doing are also vertically linked, as human practice at the lower level of the real anthropomorphizes the symbolic upper surface level grammar (Greimas and Porter 1977). Figure 1 offers a visual representation of narrative grammar for this economic universe.

Greimas' (1971) narrativity ties the networked relations of actants into a pragmatic social system, with emphasis on the syntax of 
performances for production and exchange. This narrative agency captures the roles of active individuals in the economic humanism of Perroux, and SESC emerges from the radical convergence of disjunctions, of non-ontological economy and non-economic ontology.

\section{Figure 1: The Fifth Epoch Bernácer-Perroux Economic Universe}

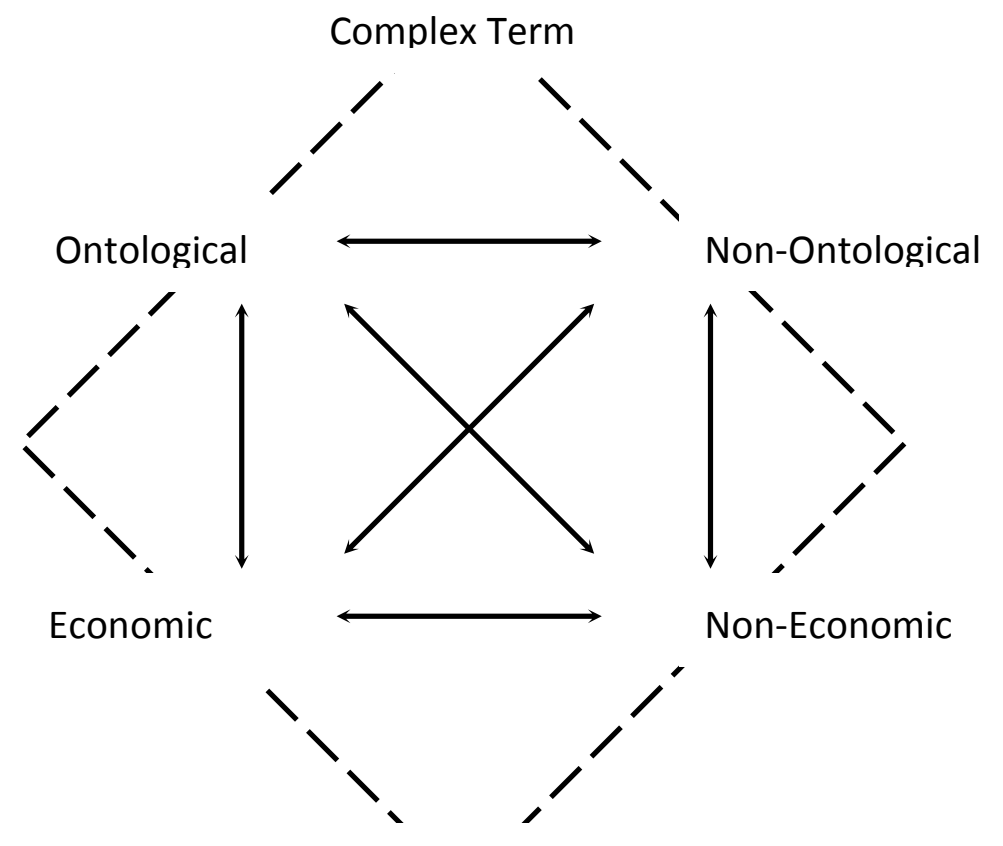

Neutral Term

When viewed as a pure abstract logic, structuralist grammar of contrary oppositions and subcontrary negations loses its grounding in storytelling, but Greimas (1971) distinguished this closed analysis of surface linguistic structures from the deeper fertile botanical morphology underlying his narrative grammar. Reading Greimas with Jameson and Lacan relaxes the rigidity of form to reconnect with life and meaning (Wegner 2009). Greimas (1971) alluded to the imaginary-real pathway of his narrative grammar. Wegner (2009) expanded that thought by overlaying the Greimas semiotic rectangle from top to bottom with Lacan's symbolic, imaginary, and real.

We have discussed how the abstraction of capital from real substance to speculative fiction has gradually reached from the top of the pyramid down into the scarce resources at the bottom. This is an economic universe of scarcity and appearance, an irreversible narrative contrived and maintained by applying a rigid grammar. The Greimas 
grammar for the fourth epoch of global capitalism is depicted in Figure 2. Comparison of Figure 2 with Figure 1 illustrates that there is no pathway from the fourth epoch to the fifth. Economic spacetime must be radically reshaped and reimagined to allow human actants an active voice to recreate an interdependent and equitable socioeconomic system.

\section{Figure 2: The Fourth Epoch}

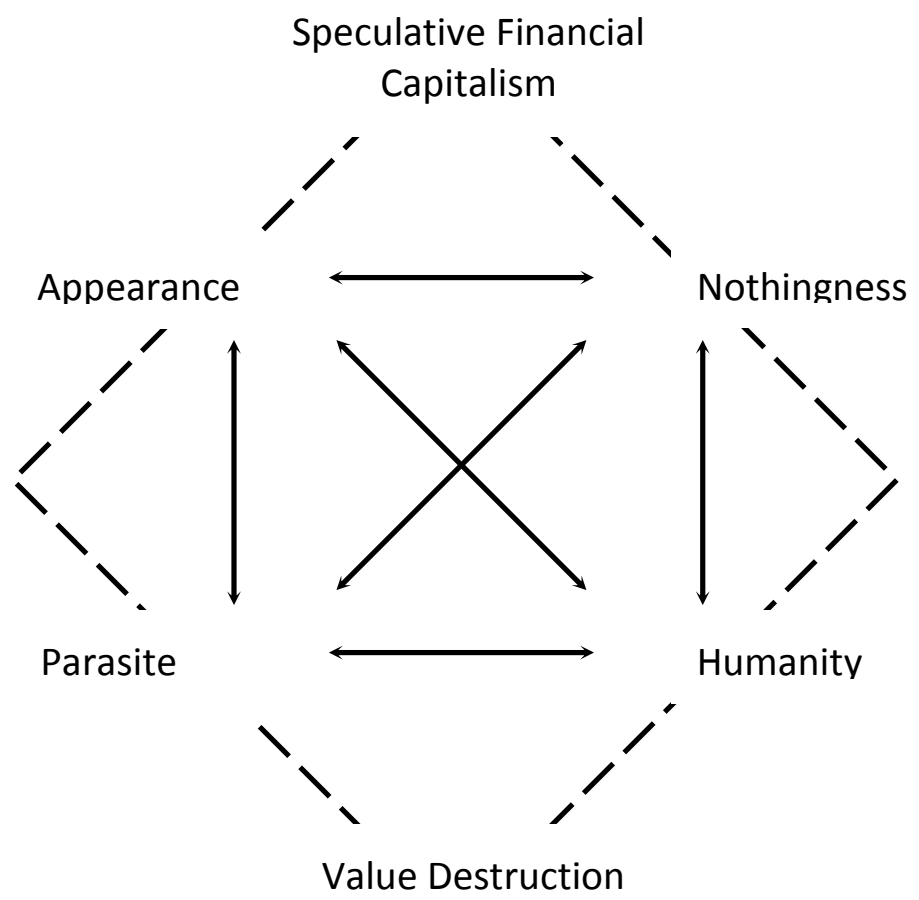

Bernácer rescues us from a speculative universe in which the appearance of social responsibility obscures the parasitical economy underneath. His resituation offers humanity a new start by reshaping the local curvatures of economic space to support real value creation and equitable rewards. Perroux restores human potential and agency to enact change. Essentially, he returns us to active roles in time, as Bergson's durée is really the human perceptual experience of place. Together, the Bernácer-Perroux structure describes the spacetime of a new economic universe. Savall's work has shown that a human economy and all other aspects of our social systems can cooperatively coexist in the disjunctive neutral term of Greimas' narrative grammar. The complex term acknowledges the ideal synthesis of being and the nihil of immanent potential. 
With a new Hegelian dialectic and Greimas grammar, the meanings of familiar terms necessarily expand. Being at the ontological vertex involves an answerability and its underlying economy expands beyond commerce to mediate all social system exchanges within and between cultures. Individual accountability is essential for sustainable enterprises, communities, and ultimately a healthy global socioeconomic system. The immanent potential from the non-ontological vertex draws support from the broad fields of social science, including organization change and development. In effect, actors freed from the singularity of speculative financial capitalism can engage in radical contradictions of economic theory to reshape sociomaterial reality. The spacetime of Savall et al. (2015) releases human potential to create value, which is reinvested to continue the positive spiral of growth and development. The beauty of SESC is not that it is the only solution, but that it shows us that other economic universes are indeed possible.

The fifth epoch is a proposal and as such should seem incomplete or indeterminate from our vantage point in the firmly entrenched fourth epoch. We have reached a dead end for fourth epoch scholarship - we must work toward a different economic reality. Thoughts for a new dialectic and a narrative grammar are intended as fodder for critical scholars because radical disjunctions and active engagement are essential to recreating a capitalism that works for everyone. Creative critical forays, conceptual and practical - in terms of transcending entrenched speculative capitalism - are happening (see, e.g., Firat and Dholakia 2016; Gibson-Graham 2008) and need to happen in many more ways, much more frequently. What cannot be allowed to happen any more is the stupor of complacency pervading the lifeworlds of those who want a better world. Therefore, in light of the work to be done to realize a different and better future, we hope that this article leaves the reader unsettled. 


\section{References}

Badiou, A. (2004), Theoretical Writings. London: Continuum.

Banerjee, A., E. Duflo, R. Chattopadhyay and J. Shapiro (2016). The long term impacts of a "Graduation" program: Evidence from West Bengal. MIT/Abdul Latif Jameel Poverty Action Lab (J-PAL). (accessed January 17, 2017) [Available at: http://economics.mit.edu/files/12031]

Banerjee, A., D. Karlan and J. Zinman (2015), "Six randomized evaluations of microcredit: Introduction and further steps", American Economic Journal: Applied Economics, 7 (1), 1-21.

Beaman, L., D. Karlan, B. Thuysbaert and C. Udry (2014). Self-selection into credit markets: Evidence from agriculture in Mali. NBER Working Paper No. 20387, (accessed June 27, 2016), [Available online at: http://www.econ.yale.edu/ cru2/pdf/selection.pdf]

Boje, D.M. (2011), Storytelling and the Future of Organizations: An Antenarrative Handbook. New York: Routledge.

Boje, D. M. (2001), Narrative Methods for Organizational and Communication Research. London: Sage.

Bruno, K. and J. Karliner (2002). Earthsummit.Biz: The Corporate Takeover of Sustainable Development. Oakland, CA: Food First Books.

Carnegie, A. (1889), "The Gospel of Wealth", North American Review, 148 (391): 653-664.

CED. (1971), "Social Responsibilities of Businesses and Corporations", Arlington, VA: Committee for Economic Development of the Conference Board.

Chabrak, N. and Y. Gendron (2015), "Promoting research from the "periphery": Engaging critically with the global financial crisis", Critical Perspectives on Accounting,30, 1-8.

Cooper, C. (2015), "Accounting for the fictitious: A Marxist contribution to understanding accounting's role in the financial crisis", Critical Perspectives on Accounting, 30, 63-82.

Cowie, J. (2016), The Great Exception: The New Deal and the Limits of American Politics. Princeton NJ: Princeton University Press. 
Dholakia, N. (2011), "Finanzkapital in the twenty-first century", critical perspectives on international business, 7 (1), 90-108.

Economist (2009), "The French model: Vive la différence!" The Economist, 7 May 2009, (accessed March 11, 2016), [Available at: http://www.economist.com/node/13610197].

Fuller, R.B. (1983), "Humanity's critical path: From weaponry to livingry", (accessed January 30, 2017), [Available at: http://www.designsciencelab.com/resources/HumanitysPath BF.pdf]

Gibson-Graham, J. K. (2008) "Diverse economies: Performative practices for other worlds", Progress in Human Geography, 32 (5), 613-632.

Greimas, A.J. (1971), "Narrative grammar: Units and levels", MLN, 86 (6), 793-806.

Greimas, A.J. and C. Porter (1977), "Elements of a narrative grammar", Diacritics, 7(1), 23-40.

Herman, D. (2012), "The missing movement: a Polanyian analysis of precrisis America", International Journal of Social Economics, 39(8), 624-641.

Hillon, Y.C. (2017), "Heroic narratives of intentional non-compliance with PRME", Society and Business Review (Forthcoming).

Hryschko, M.F. (2010). Bulgakov's sophiology as philosopheme: Nonontology and ontogenesis. Trans/Form/Ação, Marília 33 (1), 203224, (accessed March 30, 2016), [Available at: http://www.scielo.br/scielo.php?script=sci arttextandpid=S010131732010000100010]

Loiseau, J. and C. Walsh (2015). Where credit is due. J-PAL and IPA Policy Bulletin. February, 1-16, (accessed January 30, 2017), [Available

at: https://www.povertyactionlab.org/sites/default/files/publications/whe re-credit-is-due.pdf]

Maier, C.S. (1970), "Between Taylorism and Technocracy: European Ideologies and the Vision of Industrial Productivity in the 1920s", Journal of Contemporary History, 5 (2), 27-61.

Meisenzahl, R.R. and J. Mokyr (2012), "The Rate and Direction of Invention during the Industrial Revolution: Incentives and Institutions", in The Rate and Direction of Inventive Activity 
Revisited, J. Lerner and S. Stern, eds. Chicago: University of Chicago Press, 443-479, (accessed April 3, 2016), [available at http://www.nber.org/chapters/c12364.pdf].

Nicolaidis, A. (2010), "Relational nature", in The Trinity and an Entangled World: Relationality in Physical Science and Theology, J. Polkinghorne, ed. Grand Rapids, MI: William B. Eerdmans Publishing Company, 93-106.

Onorati, J. (2007), "Debating economic anthropology within a primitive context", Emory Endeavors in World History, 1, (accessed January 30, 2017) [Available at: http://history.emory.edu/home/documents/endeavors/volume1/Joey s.pdf]

Ó Gráda, C. (2014), "Did science cause the industrial revolution?", Dublin: UCD Centre for Economic Research Working Paper Series, (accessed January 16, 2016), [Available at: https://www.ucd.ie/t4cms/WP14_14.pdf]

Özgün, A., N. Dholakia N. and D. Atik (2017), "Marketization and Foucault", Global Business Review, 18 (3S) 1-12.

Prahalad, C.K. and S. L. Hart (2002), "The fortune at the bottom of the pyramid", Strategy+Business, 26 (1), 1-14.

Richard, J. (2015). The dangerous dynamics of modern capitalism (from static to IFRS' futuristic accounting). Critical Perspectives on Accounting 30, 9-34.

Savall, H. (1981), Work and People: An Economic Evaluation of JobEnrichment. Oxford, NY: Clarendon Press.

Savall, H., and V. Zardet (2008), Mastering Hidden Costs and SocioEconomic Performance. Information Age Publishing.

Savall, H. and V. Zardet (2011), "Contribution de la théorie socioéconomique des organisations à la poursuite et valorization de l'oeuvre de François Perroux au XXle siècle", in Humanisme et travail chez François Perroux, E. d'Hombres, H. Savall, and E. Gabellieri eds. Paris: Economica, 21-40.

Savall, H. and V. Zardet (2014), "Action research and intervention research in the French landscape of organizational research: The case of ISEOR", International Journal of Organizational Analysis, 22 (4), 551-572. 
Savall, H., M. Peron, V. Zardet and M. Bonnet (2015), Le Capitalisme Socialement Responsible Existe. Cormelles-le-Royal, France: EMS.

Smith, W.L. (2015), "Tetranormalization and the accounting standardsetting process: A Retrospective view of the Accounting Principles Board", in Organizational Change and Global Standardization: Solutions to Standards and Norms Overwhelming Organizations, D.M. Boje, ed. New York: Rutledge, 69-80.

Stiglitz, J.E. (2012), The Price of Inequality. New York: W.W. Norton and Company.

Wegner, P.E. (2009), "Greimas avec Lacan; Or, from the symbolic to the real in dialectical criticism", Criticism, 51 (2), 211-245.

Wood, M. D. (2013), "Beyond the ethics of wealth and a world of economic inequality", Buddhist-Christian Studies, 33, 125-137.

Yurdakul, D., D. Atik and N. Dholakia (2017), "Redefining the bottom of the pyramid from a marketing perspective", Marketing Theory, forthcoming, DOI: 10.1177/1470593117704265

Zhang, W.B. (2015), "How do the richest $1 \%$ own $50 \%$ of global wealth in and integrated Walrasin-general-equilibrium and Oniki-Uzawa's trade theory", Journal of Academic Research in Economics, 7(1), 744.

Žižek, S. (2012), Less than nothing: Hegel and the shadow of dialectical materialism. London: Verso Books. 